MAKING THE PAPER

\section{Barry Dickson}

Nature Vol.446(xi)/29 March 2007

\section{ショウジョウバエの交尾行動 を制御するフェロモン受容体}

ウィーンにある分子病理学研究所の Barry Dicksonたち がショウジョウバエの交尾習性の研究に取りかかったの は、 5 年ほど前のことだ。彼がめざしていたのは、行動 を制御する脳内の神経回路を解明することで、その出発 点として交尾行動は格好の材料に思えたのである。「交 尾行動は安定した行動の1つで、ショウジョウバエはこ の行動を実に上手にやってのける」とDicksonはいう。

ショウジョウバエでは、性別に特異的な行動が、神経 系で発現されるfruitless という遺伝子に制御されている。 Dicksonたちは 2005 年に、匂いを感知する 50 種類の ニューロンのうち 3 種類でこの fruitless が発現しているこ とを見つけた。そこで彼は、これらの「fruitlessニュー ロン」は性フェロモンを感知しているのではないかと考 えた。性フェロモンは動物が作り出す化学物質で、同じ 種のほかの仲間に自分の性別や交尾の意思といった情報 を知らせる働きをする。

Dicksonは性フェロモンに関して、ある手がかりを握っ ていた。3種類の「fruitlessニューロン」のうち 1 種類は、 雄の性フェロモンであるcVA (11-cis-vaccenyl acetate) を感知すると考えられている受容体も発現していたので ある。大学院生のAmina Kutrovicが、cVA受容体と考 えられている遺伝子をもたないショウジョウバエを遺伝子 操作によって作り出し、ポスドクのAlexandre Widmer の助けを借りて、それらのハ工の行動を調べた。

正常であれば、雄バ工は雌バ工に求愛行動を示し、雄 か雄に求愛することはなく、また、雌は雄と交尾する。と ころが、cVA受容体をもたない変異体の雄バエは雄に向 かって求愛行動を示し、同じ変異をもつ雌バ工は交尾をあ まりしたがらなかった。そこで、CVA受容体の活性化は雌 と雄で正反対の作用を及ぼすと思われた。つまり、雄では 交尾行動を抑制し、雌では交尾行動を促進するのである。

この考え方をさらに検証するため、研究チームは雄バ工 に遺伝子操作をして、正常であれば本来はcVA受容体を

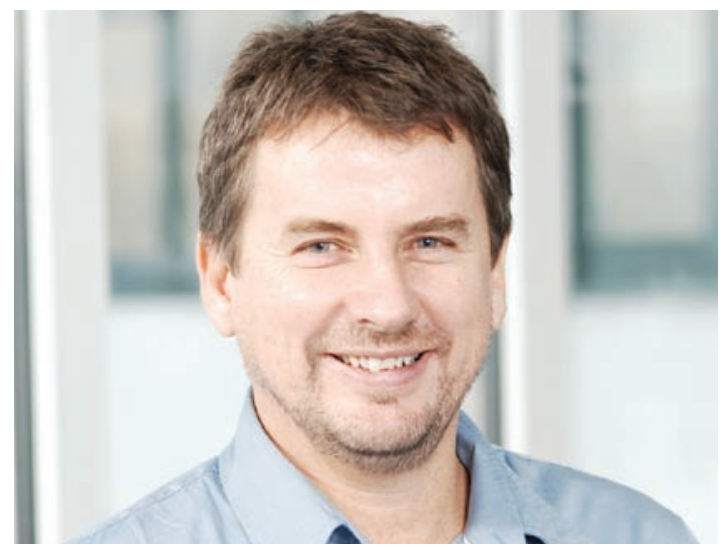

発現する種類のニューロンが、雌のガが発する性フェロモ ンの受容体を発現するようにした。次に、雌バエの腹部に この雌ガの性フェロモンをなすりつけ、雌バエから雌のガ の匂いがするようにした。すると、ガの性フェロモン受容 体を発現する雄バエは、雌ガの匂いのする雌バエを敬遠し たが、ガの性フェロモン受容体をもたない雄バエはいそい そと、雌ガの匂いのする雌バエに求愛した (Nature 2007 年3月29日号の 542 ページ参照)。研究チームは、一見す ると直観に反したこの結果から、雄の求愛行動を抑制する には、正常にCVA受容体を発現しているニューロンの活性 化が必要かつ十分条件であることを悟ったのである。

腐りかけの果物の匂いのように日常的なありふれた匂 いは、各種のニューロンにある多種多様な受容体を活性 化させ、活性化した複数の受容体の組み合わせによって 匂いが符号化される。しかし、フェロモンのように生物 にとって特別な重要性をもつ匂いは、1種類の嗅覚二ュー ロンを活性化させて、明確な1つのシグナルを脳へ伝え ているのかもしれない。

$c V A$ に対する雌雄の反応の違いは、シグナルが脳内で どのように処理されるかで決まるとDickson は考えてい る。「感覚情報処理は一見すると、雌雄で同じにみえる」 とDicksonはいう。「雌雄の違いがどこで生じるのか厳 密にはわからないが、嗅覚ニューロンそのものが違いを 生じる場所ではないようだ」。

彼の研究チームは現在、CVA受容体からのシグナルを 処理する高次の経路を追跡しているところだ。「こうした 化学シグナルが神経回路を活性化して行動を引き起こす 仕組みを知りたいと思っている」と彼は語る。「fruitlessと Or67dの2つの遺伝子はヒトには存在せず、そのためこれ らの知見をヒトの行動に直接当てはめることはできない。 けれども、相同性ではなく類似性を探すことで、ほかの種 にこの結果を拡大し応用することができるかもしれない」。 